of Anthropology, Moscow State University. The skull of an early Inca or Pre-Inca individual showing seven trephinations which the owner survived, collected at Pachacamae, in the Department of Lima, Peru, by the late Dr. D. S. Matthews, has been presented by the British Andean Expedition to Mount Huageruncho (1956). An exchange has been arranged with the Meteorite Committee, Academy of Sciences of the U.S.S.R., Moscow, through Prof. E. L. Krinov, by which specimens of ten meteorites hitherto unrepresented in the Museum's collection at South Kensington have been acquired.

\section{Supplies of Anterior Pituitary Hormones}

Frve of the individual Institutes of the National Institutes of Health, Bethesda, Maryland, are jointly providing the funds for the purchase or production of large uniform lots of anterior pituitary hormones, other than adrenocorticotropic hormone, purified to meet exacting specifications set by the Endocrinology Study Section both for potency and for low limits of contamination with other activities. The first lots of bovine growth hormone and of ovine prolactin have been approved by the Study Section and are ready for distribution. The growth hormone and prolactin are packed as sterile, lyophilized powders in vials of $50 \mathrm{mgm}$. and $25 \mathrm{mgm}$. respectively. Data on the estimated potency and degree of contamination, and instructions for dissolving the materials, are issued with each package. A pilot plant at Emory University is being set up under the direction of Drs. Stanley Ellis and Alfred E. Wilhelmi for the production of follicle-stimulating, luteinizing and thyrotrophic hormones. These materials will not be ready for some months. Grants of the hormones will be made to qualified investigators who apply to the Endocrinology Study Section, c/o National Institutes of Health, Bethesda 14, Maryland. Application may be made by letter giving a brief description of the proposed work, together with an estimate of the amount of hormones required. It is hoped that by this service both clinical and fundamental studies on the anterior pituitary hormones will be stimulated.

\section{The Mond Magazine : a Journal on Products from} Nickel-containing Ores

For a quarter of a century the Nickel Bulletin, published by the Mond Nickel Co., Ltd., has provided a monthly summary of the world's literature relating to nickel and nickel-containing materials. The Company has now instituted the publication of The Mond Magazine, which is intended to have a wider scope and different functions, though it will not, fortunately, supersede the Bulletin itself. The object of the new publication is to provide articles and notes on a wide variety of subjects related to all the products extracted from the Sudbury ores, which, in addition to the nickel, contain copper, cobalt, gold, silver, the platinum metals, selenium, tellurium, sulphur and iron ore. In the first issue (No. 1, July 1956 ; pp. 24) are articles on terramycin, the plant for which is constructed of a nickel-chromium corrosion-resisting steel; a short note on palladium in relation to its use in jewellery ; stained-glass windows, in which cobalt, selenium and nickel, etc., are used as colouring matters; nickel-chromium steels in steering-rod assemblies; high-nickel cast iron; the use of nickel-chromium-molybdenum steel in the oxygen equipment for the 1955 Kangchenjunga expedition; the resistance of platinum to molten glass; and mechanical excavators. It is clear that this new publication, which can be obtained free of charge from the Publicity Department, Mond Nickel Co., Ltd., Thames House, Millbank, London, S.W.1, should interest a very wide variety of new readers.

\section{Prehistoric Wooden Implements from Africa}

Besines a note by Dr. A. S. Brink on some Thecodonts, Part 6, Vol. 1, "Researches of the National Museum, Bloemfontein", contains an interesting article by Dr. Desmond Clark on a wooden implement from the level of Peat I at Florisbad, Orange Free State. Florisbad is not a very satisfactory site. There are peats of various ages at these fossil springs, and when, as in 1912, local upheavals occur, their contents all tend to get mixed up. However, all the levels seem to be referable to some time in the Gamblian period. It is rare for wooden objects to have survived from prehistoric times. Only in exceptional circumstances can this occur. Dr. Clark, however, has himself unearthed an even more interesting example at a site (Kalambo) near Aber. corn in Northern Rhodesia. Here the date is definitely late Acheulean. In both cases the working is of a simple order and not in itself of much importance; but the use of wood by very early man for tool. making purposes is now definitely established.

\section{Bassi's "Del Mal del Segno"}

To mark the centenary of the death of Agostino Bassi (see Nature, 177, 255 ; 1956), the University of Pavia has issued an attractive photographic-offset facsimile of the two parts of Bassi's monograph, "Del Mal del Segno" $(1835,1836)$. Loosely inserted is a brochure in which a note on the commermorative edition by Antonio Pensa is followed by a reprint of the appreciation of Bassi by G. B. Grassi from the collected edition of Bassi's works published in 1925, a list of the changes Bassi mado in the second edition (I837) of "Del Mal del Segno", and a catalogue of Bassi's writings. A limited number of these facsimiles are for sale. Inquiries should be made to the Rector of the University of Pavia, Italy.

\section{Royal Society Antarctic Expedition}

THE main party of the Royal Society Antarctic Expedition for the International Geophysical Year (July 1957-December 1958) under the leadership of Colonel Robin Smart will leave London on November 15 for Royal Society Base, Halley Bay, in the M.S. Magga Dan, which is being shared with the TransAntarctic Expedition. The party will relieve the advance party of ten men under the leadership of Surgeon Lieut.-Commander D. Dalgliesh who sailed from Southampton in November 1955 in the M.V. Tottan, and most of them will remain at Halley Bay until January 1959.

\section{Oversea Service Division, Colonial Office}

THE following appointments have recently been made in the Over'sea Service Division, Colonial Office: J. M. Arthurs (rural education officer, Federation of Nigeria), principal of the Farm Institute, Arapai, Uganda; D. R. N. Brown (assistant director of agriculture, Uganda), deputy director of agriculture, Uganda; V. E. M. Burke (assistant agricultural officer, Kenya), agricultural officer, Kenya; L. F. Derraugh (senior agricultural officer, Gold Coast), commissioner for food products, Department of Agriculture, Gold Coast; E. W. Findlay (agricultural officer, Eastern Region, Nigeria), senior 